\title{
Mapping and Characterization of the Landscape Units of the Coastal Hydrographic Basin of Rio Pacoti, Ceará, Brazil
}

\author{
Álvaro Andrade Dourado¹, José Falcão Sobrinho ${ }^{1,2}$ (), Francisca Edineide Lima Barbosa1 (i), \\ Ernane Cortez Lima1 ${ }^{1}$ (i) \\ ${ }^{1}$ Vale do Acaraú State University, UVA, Ceará, Brazil \\ ${ }^{2}$ Semi-Arid Research and Extension Group/CNPq, Ceará, Brazil \\ Email: alvaro-dourado1@hotmail.com, falcao.sobral@gmail.com, edineidelb@gmail.com, ernanecortez@hotmail.com
}

How to cite this paper: Dourado, Á.A., Sobrinho, J.F., Barbosa, F.E.L. and Lima, E.C. (2021) Mapping and Characterization of the Landscape Units of the Coastal Hydrographic Basin of Rio Pacoti, Ceará, Brazil. Journal of Geographic Information System, 13, 260-273.

https://doi.org/10.4236/jgis.2021.132014

Received: March 11, 2021

Accepted: April 23, 2021

Published: April 26, 2021

Copyright $\odot 2021$ by author(s) and Scientific Research Publishing Inc. This work is licensed under the Creative Commons Attribution International License (CC BY 4.0).

http://creativecommons.org/licenses/by/4.0/

\begin{abstract}
Attention must be in identifying and managing watershed landscapes because of the importance of preserving natural resources. Therefore, this manuscript identifies and maps the coastal area of the Pacoti River Watershed. The methods were the analysis of landscape maps from Ceará research agencies and fieldwork to verify the information. The conclusion is that using technology has become a decisive and effective factor when identifying and analyzing physical characteristics in geomorphologic compartments in the Pacoti River Watershed.
\end{abstract}

\section{Keywords}

Watershed, Landscape, Geo-Technology, Coastal Zone

\section{Introduction}

The Pacoti River Watershed (Figure 1) is a sub-basin of the Great Metropolitan Basin. Its area, around 132,717.60 hectares, corresponds to $8.83 \%$ of the Metropolitan Basin, which has one million and five hundred hectares.

Some compartments that stand out because of their fragility are in the coastal zone, such as estuaries, dune fields, and post-dunes, which are the principal. Although such environments suffer intense modification caused by the coast dynamics, they are steady depending on the continental region. Such ecosystems have a significant landscape potential, high levels of terrestrial natural resources, intense dynamics, and vulnerability [1].

The Brazilian legislation subdues improper occupation in the coastal zone. It 


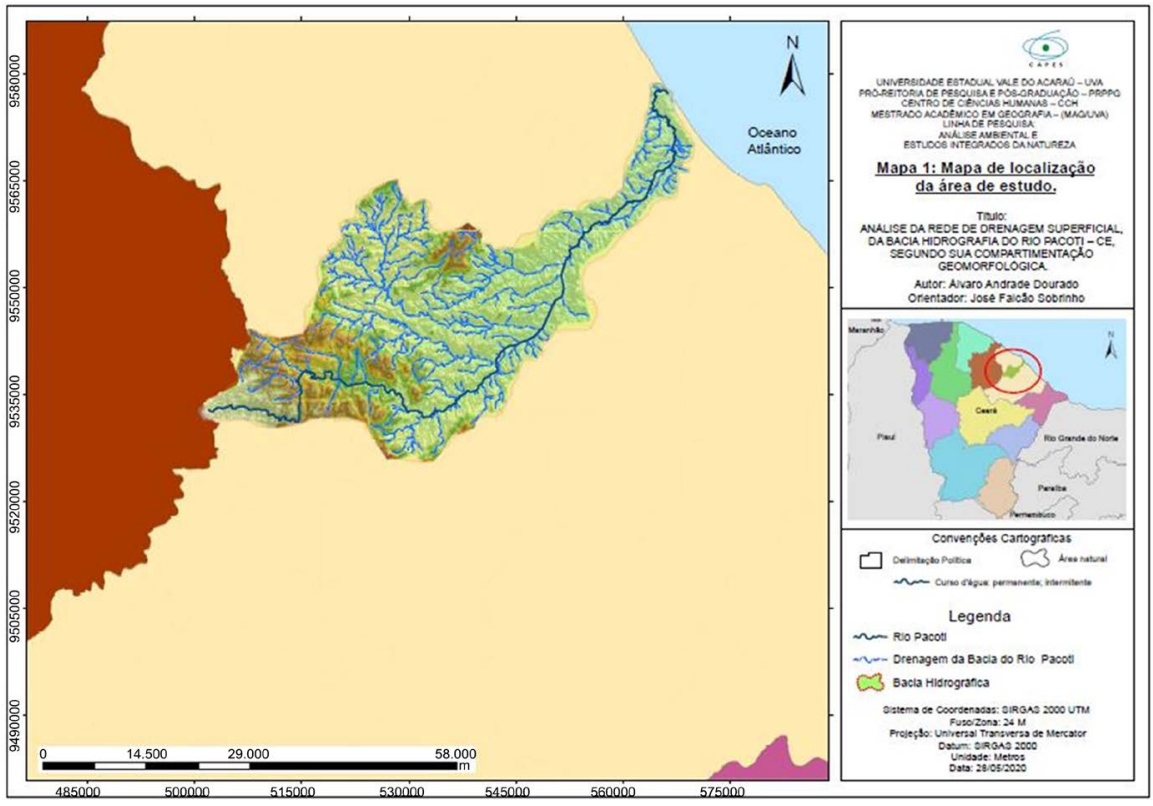

Figure 1. Location map of the studied area. Source: made by the authors (2020).

recognizes the importance and fragility of such areas in the environment established by Federal Law 12651/12, which has rules and guidelines to preserve, maintain balance and well-being.

Considering the assumptions surrounding the environmental problems caused by nature and human action, one should not only focus on identification techniques, but also understand the process in which they are involved. Therefore, studies with references in the geographical space help to understand the environmental dynamics. It requires the mapping of these environments using, under these conditions, the systemic method as a research reference.

\subsection{Technical and Methodological-Operational Guidance}

The research has foundations on the General System Theory proposed by the German biologist Ludwig von Bertalanffy in 1930, based on the Pacoti River Watershed. In this perspective, when making a geographic study, it is necessary to use the concept of system to understand the complex issues as they are interdependent, that is, the variable natural units inserted in the study area.

Thus, in a systemic approach, watersheds integrate a joint vision of the behavior of natural conditions and human activities developed in them, since significant changes in any of these units can generate changes, effects, and negative or positive impacts. As a rule, it establishes the relief as a possible unit to map more expressively without losing the sense that they are related [2], Figure 2.

To the author, the structural elements (rock, climate, and water) that make up the scenario of natural landscapes comprise in this study the exploitation potential constituted by the elements (soil, vegetation, and water) that make up the system. They unfold in the relief and results in the interaction of social actions originating the derived landscapes. 


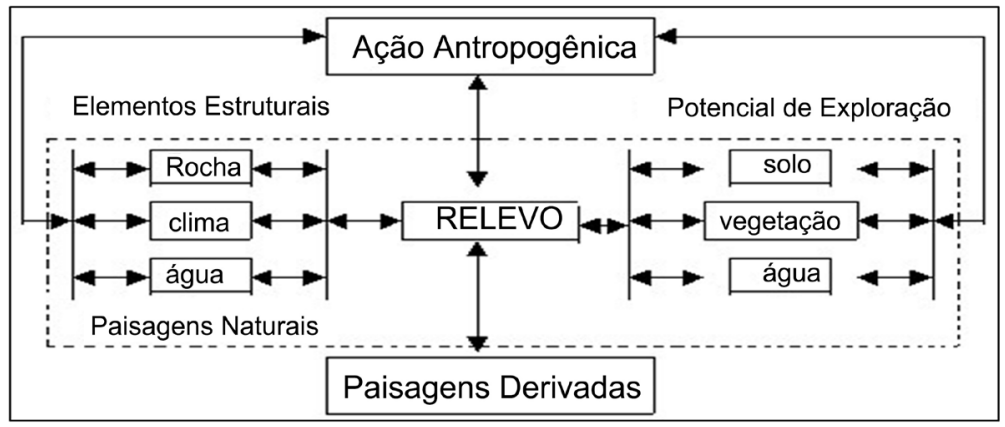

Figure 2. Relief, the stage for joint landscape. Source: SOBRINHO, Falcão (2007) [2].

\subsubsection{Literature}

Data were collected from rainfall stations over 20 years at the Fundação Cearense de Meteorologia (Meteorology Foundation of Ceará [3] in the municipalities of Aquiraz and adjacent areas, which is part of the behavioral analysis of the rainfall regime in the area. This stage seeks to understand the relief formation in the landscape at different times of the year according to the rainfall regime in Ceará.

Stations selected from the portal [3] provided data for the analysis of the rainfall indexes. The selected ones, three in different cities, represent distinct areas related to the geomorphological unit in that place.

The first station is in the municipality of Guaramiranga (latitude $4^{\circ} 16^{\prime} 1.20^{\prime \prime} \mathrm{S}$ and longitude $38^{\circ} 55^{\prime} 59.90^{\prime \prime} \mathrm{W}$ ), the second one in Horizonte (latitude $4^{\circ} 5^{\prime} 60.00^{\prime \prime} \mathrm{S}$ and longitude $38^{\circ} 28^{\prime} 59.90^{\prime \prime} \mathrm{W}$ ), and the third one in Aquiraz. Each one portrayed a geomorphological unit-the humid residual massif in Serra de Baturité, the planing surface, and the coastal zone. The yearly, monthly, and daily data were between 1974 and 2019.

\subsubsection{Cartographic Material and Georeferenced Bases}

Not only cartographic data collected from reliable sources, such as public agencies, [3] [4] [5], contributed to this research, but also manuscripts found in various libraries. The maps were the Multimodal Map of the State of Ceará, scale 1:900,000, 2013, DENIT; Map of the Geoenvironmental Compartimentalization Macroregion of Planning, scale 1:6,000,000; Simplified Geological Map of Ceará, scale 1:600,000; Map of the Phytoecological Units of Ceará, scale 1:600,000, FUNCEME; Map of Climatic Types of Ceará, scale 1:600,000 [3] [6].

Cartographic material, georeferenced data, geographyc information system (GIS), and geoprocessing data software assisted in the production of maps that show the Pacoti River dynamics. Geostatistical methods, such as interpolation of data by kriging or IDW (Inverse Distance Weighted), also aided the production.

Geoprocessing software [7] also contributed to the production of slope maps, classifying the landscape relief based on the results found in percentages after digital processing of the data, as seen in Table 1 .

The orbital images from the TM LANDSAT 8 satellite supported the extraction of information regarding the topic. The composition used was band 543 in 
Table 1. Relationship between the slope types and relief.

\begin{tabular}{cc}
\hline Slope type (\%) & Relief \\
\hline $0-3$ & Floodplain \\
$3-6$ & Plain to gently undulating \\
$6-12$ & Gently undulating to undulating \\
$12-20$ & Undulating to heavily undulating \\
$20-40$ & Heavily undulating to mountainous \\
$>40$ & Mountainous \\
\hline
\end{tabular}

Source: made by the authors (2020).

the RGB (RED, GREEN, BLUE) spectrum in digital format. The image processing happened through MAPGEO 1.0, Spring 5.5.2, and QGIS 3.0.3. Functions related to the classification and treatment of images aimed at extracting spatial information relating to vegetation, land use, hydrography, road network, and urban areas.

Through ArcGIS 10.2, the maps had a 1:100,000 scale. With geoprocessing techniques, the developed research models assisted the detection, identification, qualification, and cartographic quantification. The use and occupation of the land underwent monitoring along with the analysis of the environmental impacts. The data and information from the surface and the phenomena and processes involved followed according to methodology [8].

The methodology proposed [9] aided the interpretation of the orbital images. The connection between visualized elements and the environmental characteristics took place by using interpretation criteria in orbital images through the texture, color, shape, size, volume, and location.

For the author [9] the methodological basis used for compartmentalization should be the integrated study of a systemic nature, using remote sensing, using the technique of visual interpretation of ETM/LANDSAT 7 satellite images, which has basic information resulting in better and more complete data in understanding the environment. The application of this approach allows observing the integrated set of the environment and separating it into different units, presenting a systematic process based on an integrated conception of the environment, its components, structuring and active processes.

The interpretation was through the image segmentation function in SPRING 5.5.5, a Brazilian software for a geographic information system that had its origin in the Instituto Nacional de Pesquisas Espaciais (National Institute for Space Research, INPE) [10]. The segmentation consists of the identification and delimitation of the areas identified in the image.

\section{Result and Discussion}

Studies, analysis of georeferenced databases from government agencies, and fieldwork show a different physical characterization in the Pacoti River Watershed coastal zone. Thus, one can identify the climate condition, geological di- 
versity, geomorphology, soil, vegetation, land use and occupation, and conservation units.

\subsection{Climate}

The area in the Pacoti River Watershed is a coastal zone, represented by Eusébio and Aquiraz. The climate is the sub-humid tropical warm (Figure 3), which goes from the coastal region to half of the Great Watershed area.

From data collected by the rainfall stations, the choice for Aquiraz was because it generally represents the coastal zone and a large amount of rainfall data among the collection stations of the nearby municipalities.

In the coastal zone, the rainfall levels are relatively higher than in other towns in Ceará because of the proximity to the ocean. Therefore, the evaporation rate is higher, contributing decisively to higher precipitation levels (Figure 4).

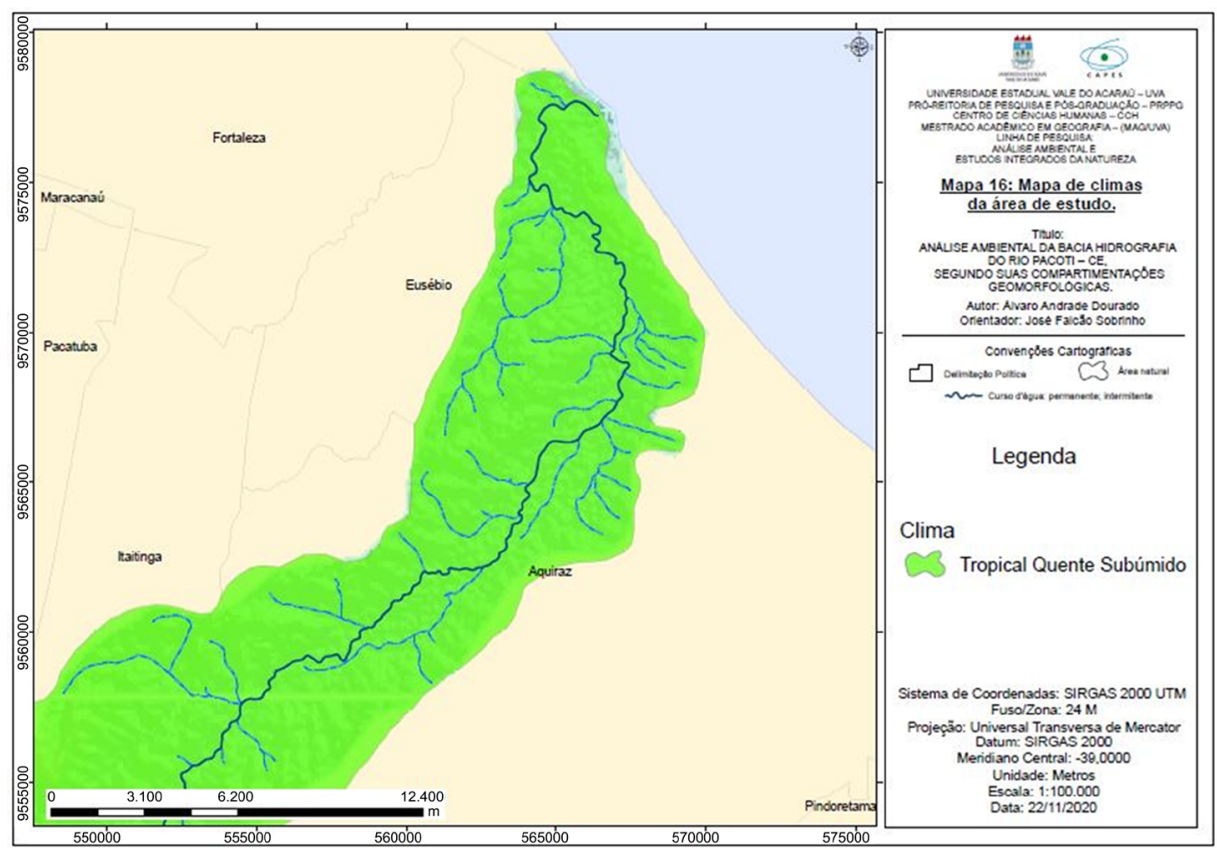

Figure 3. Climate map in the coastal zone. Source: made by the authors (2020).

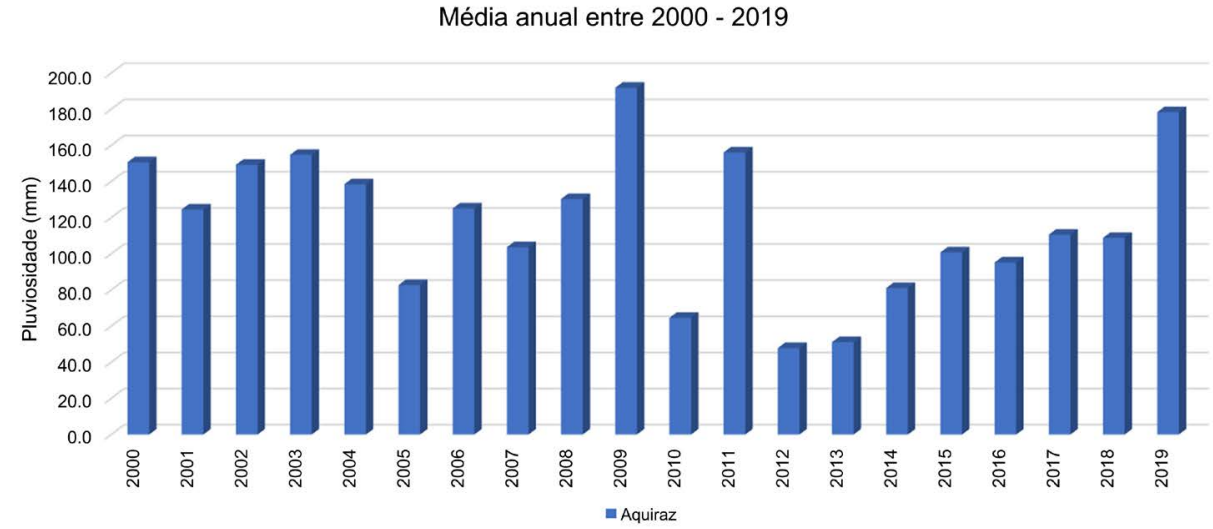

Figure 4. Rainfall annual average in Aquiraz. Source: adaptation from FUNCEME data [3]. 
In Figure 5, it is possible to make a monthly analysis regarding the rainfall averages distributed throughout the year. The rainy season in the state of Ceará is in the first half of the year, more precisely in the first four months.

The figure below proves that the highest averages over the year are in March, April, and May, whose values are even higher than other regions in Ceará.

\subsection{Geology}

The coastal tablelands represent ancient depositional surfaces presenting extremely smooth gradients towards the coastline. These relief forms are dissected by a network of channels of low drainage density and dendritic pattern, forming shallow u-shaped valleys with, at most, 20 meters of unevenness.

Towards the countryside, the tablelands are fragments amidst the crystalline outback surface because of the partial removal of this sedimentary capping. It indicates a significantly broader and more continuous original coverage of the Barrier Group, which extended for several tens of kilometers into Ceará and may have reached the foot of the Baturité massif [11].

Using the cartographic bases used to make the maps (Figure 6), one can identify a range of geological units. Six kinds-Holocene Alluvium, Barrier Formation, Holocene Aeolian Cover, Canindé and Independência Units, Marsh Deposits, and Holocene mangroves-were identified in the coastal zone of the Pacoti Watershed.

The Barriers Formation is near the main course of the Pacoti riverbed, while the Holocene swamp deposits are at the mouth. The region has characteristics, such as salinity and amount of nutrients, for the development of mangroves.

\subsection{Geomorphology}

Several phenomena of planetary magnitude influence the morphology of coastal zones. The most important are plate tectonics, climate, and relative sea-level variations. The movements between the continental and oceanic plates determine the type of coast and its orientation concerning exposure to waves and

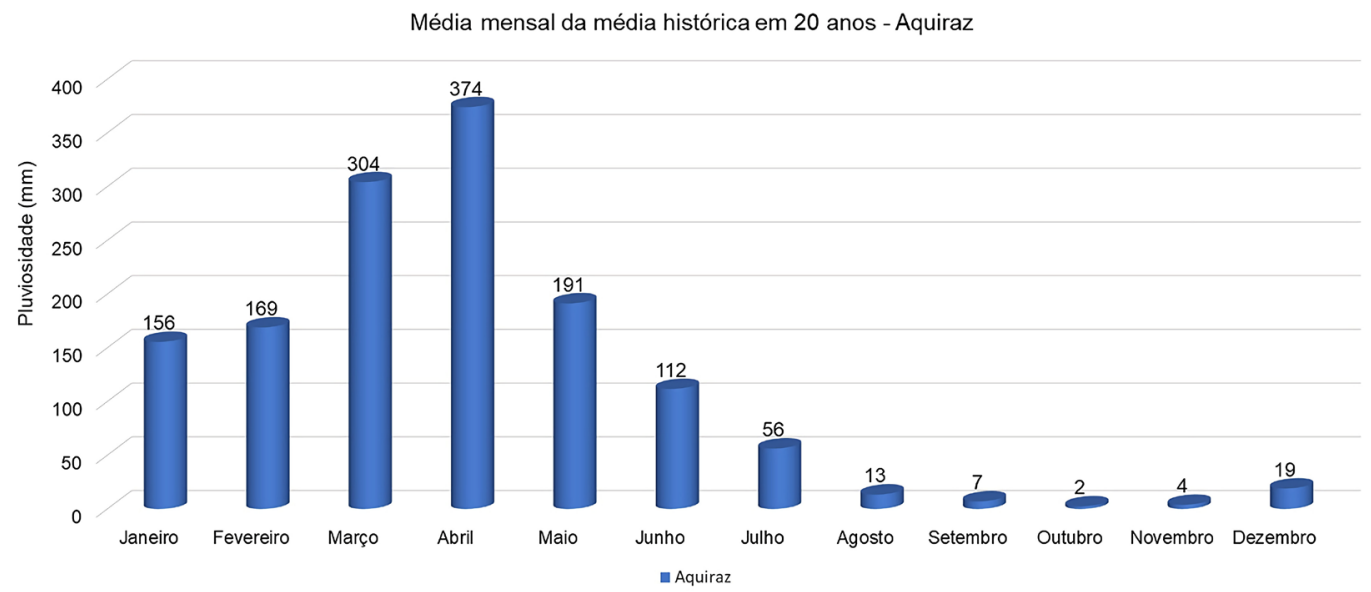

Figure 5. Monthly average in Aquiraz. Source: adaptation from FUNCEME data [3]. 


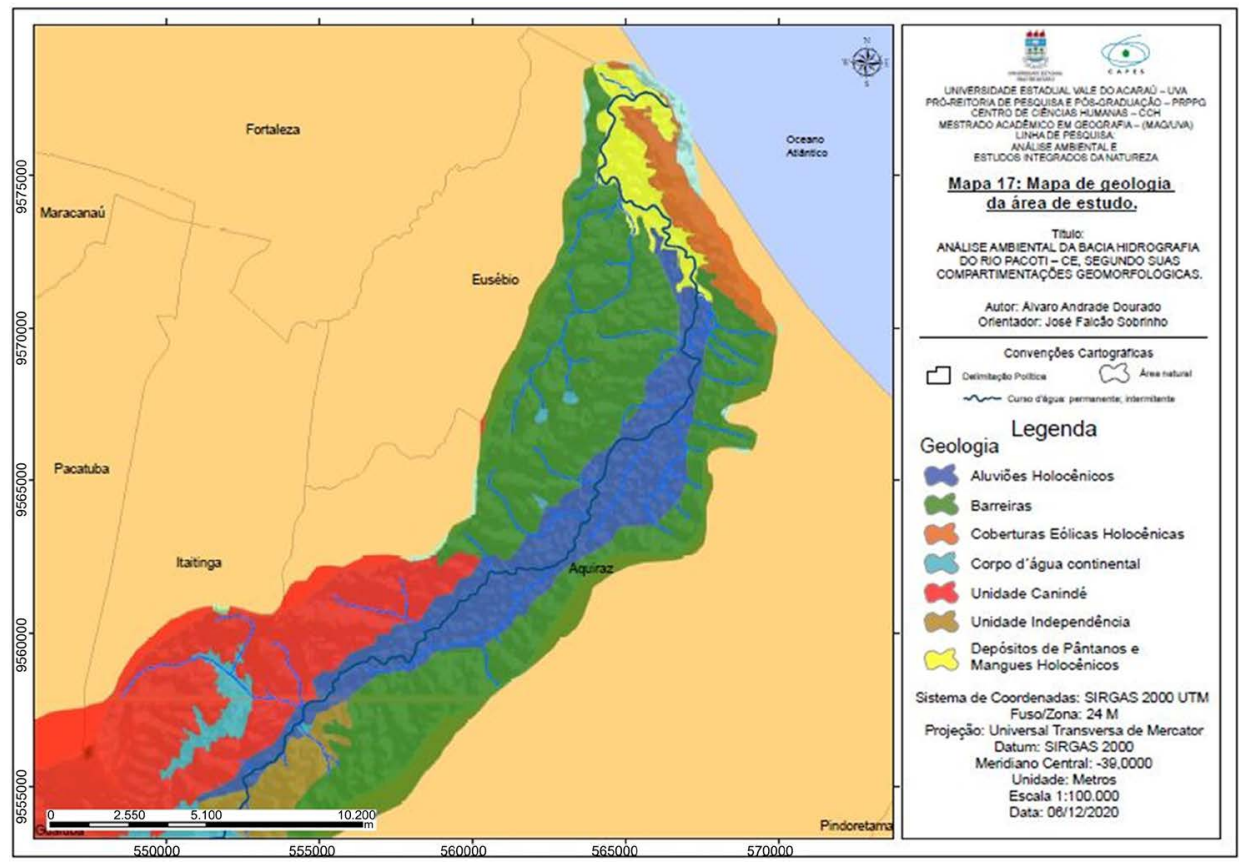

Figure 6. Coastal zone geological map. Source: made by the authors (2020).

currents. The climate controls continental erosion, is responsible for sea-level oscillations, and influences the coastal plain evolution [12].

About 120 million years ago, the Ceará coastline did not exist, Africa was still joined to South America, forming Oceania, and India and Antarctica formed the supercontinent Gondwana. The complete rupture of the South American and African plates occurred between 100 and 99 million years ago, during the Cretaceous period of the Mesozoic Era. This process originated the equatorial segment of the South Atlantic and the continental margins of Northeast and West-Central Africa, which slid relative to each other [12].

It is possible to identify, according to Figure 7, that the main geomorphological features in the coastal zone are mobile and fixed dunes and pre-coastal tablelands.

The pre-coastal tablelands go laterally along the coastal zone, mainly in the area after the beach, and often do not reach long distances towards the continent. There are lots of summer houses, and property speculation is prevalent in such a region. Besides, the area suffers from other forms of environmental degradation. The fixed and mobile dunes, which are tourist attractions, are close to the sea bed.

\subsection{Soil}

The coastal plain of Ceará extends over a long stretch of land between the coastline and the coastal tablelands, although it is narrow, covering almost all the Ceará coastal zone. Directly linked to the river mouths, the fluviomarine plains are developed, standing out the mangroves that occur on the margins of the estuaries or river mouths that flow into different regions of the coast [11]. 


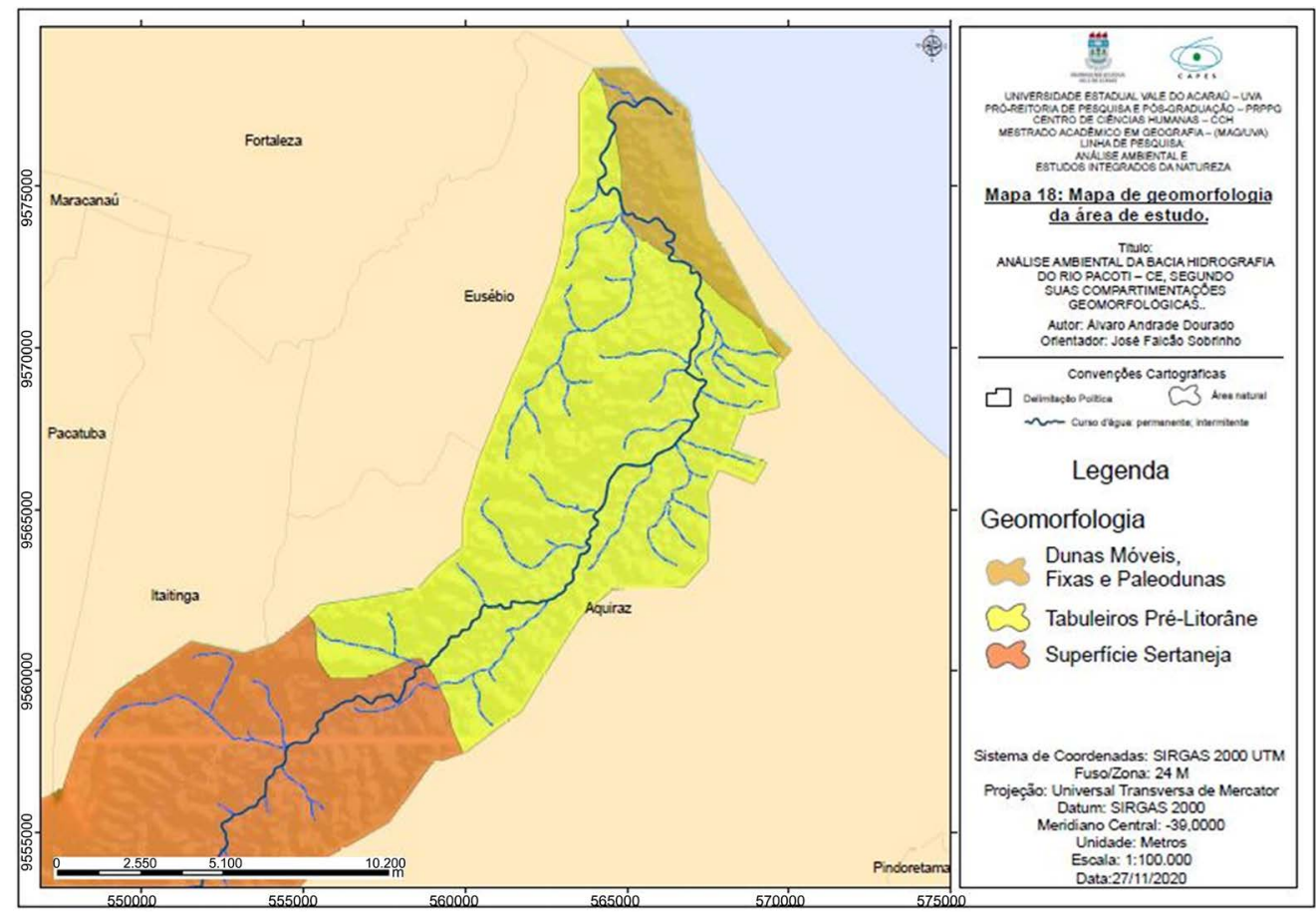

Figure 7. Coastal zone geomorphological map. Source: made by the authors (2020).

According to the author [11] states that predominantly, the fluviomarine plains are developed on soils with quartz characteristics, deep, with little adhesion and cohesion between its particles, and low retention capacity of moisture and nutrients, constituting Quartz Neosol in most of the land.

Based on cartographical bases and under the graphic scale adopted in the produced maps-scale 1:100,000-that aim at a macro view of the region, the type of soil found in the coastal zone of the watershed is the Red-Yellow Acrisol, as seen in Figure 8.

According to the authors [13], the Red-Yellow Soils serve the cultivation of sugar cane, fruits (jackfruit, mango, banana, sapota, citrus, coconut, acerola), pasture (brachiaria, pangola-grass, and elephant grass), cassava, passion fruit, and yam. For rational use, they need fertilization and liming because they are soils of low natural fertility. In the areas where crystalline rock and sub-deciduous forest prevails, the Red-Yellow Soils serve the cultivation of mango, coconut, pastures, among other uses.

The natural fertility level in this soil ranges from low to medium, being the reliefs in crystalline rock environments a significant limitation. In the study area, there is slightly rugged relief and the presence of crystalline rocks. In coastal tablelands, these soils need correctives and fertilizers to obtain good crop productivity, requiring the use of organic matter in the superficial horizon, especially in soils with sandy texture [13].

\subsection{Vegetation}

Soils lose a large part of their genetic seed bank because of the erosional process, 


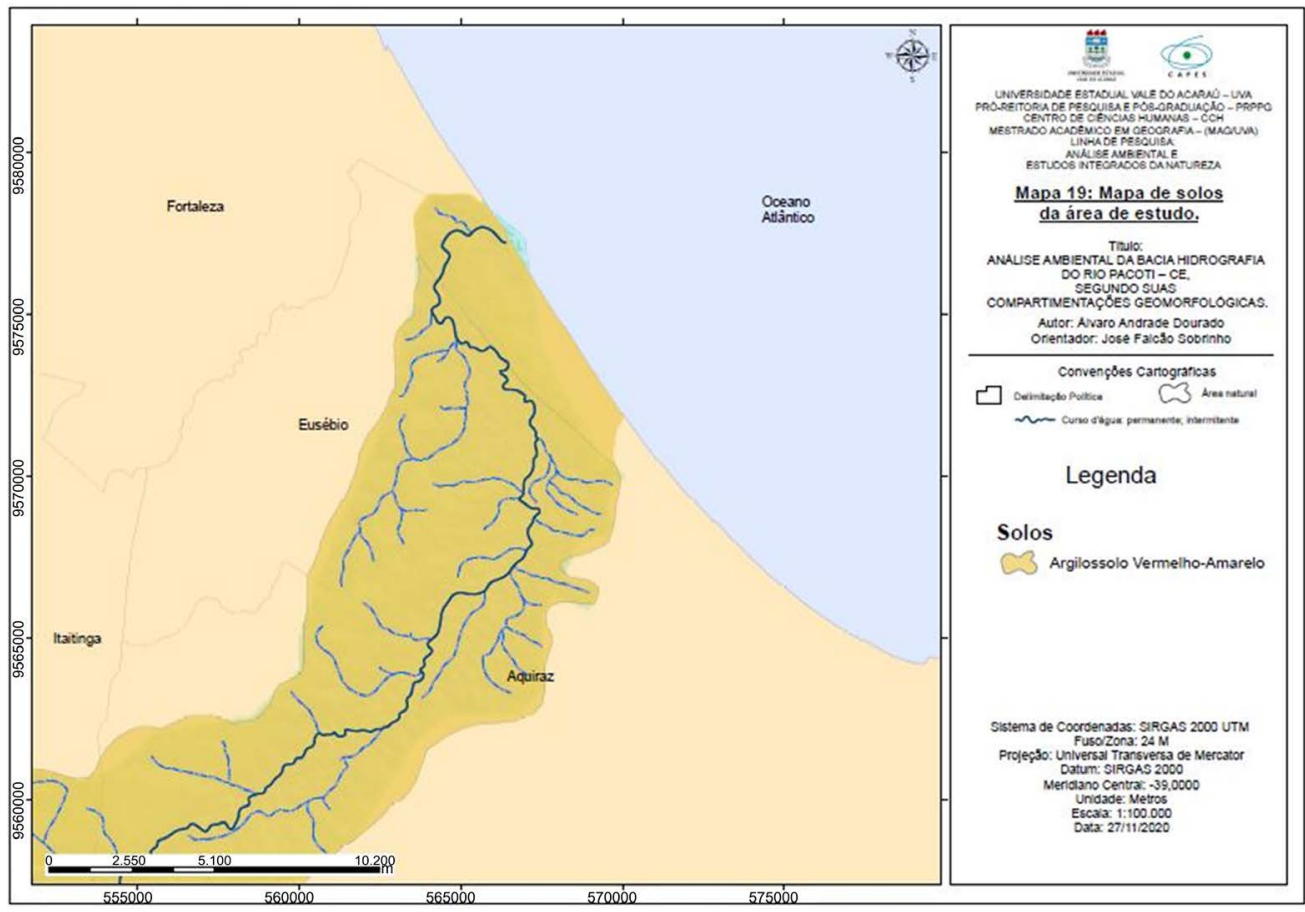

Figure 8. Coastal zone soil map. Source: made by the authors (2020).

which is a factor present in almost all regions of the state of Ceará, even in the coastal zone. Erosion makes the soil lose its surface cover, rendering natural revegetation difficult even in the rainy season. If it happens over the years, desertification starts to a certain degree.

As shown below, three phyto-ecological units are present in the coastal zone of that area, which are cerrado, coastal cerrado, coastal vegetation complex, and mangrove (Figure 9). They have adapted to the local conditions, such as temperature, climate, soil, salinity, and nutrients.

The mangrove presents greater fragility and vulnerability because it is an environment extremely sensitive to environmental changes. Its system is a typical coastal ecosystem of tropical and subtropical regions defined as transitional zones between the marine and terrestrial environments. This environment serves for fish, crustaceans, and mammals to reproduce, being a nursery for them.

By being close to the caatinga and cerrado [14], the coastal vegetational complex in Ceará is the coexistence of species from such domains and species from the restinga in other formations. Despite the ecological and botanical importance of this ecotone, there are few studies on the regional flora.

To record in which environments the species occur [14] used categories of coastal environments of the phyto-ecological unit system of Ceará [15] with adaptations and identified as constituent units of the coastal vegetational complex: Psammophilous pioneer vegetation I, Psammophilous pioneer vegetation II, fixed dunes forest and dune rear, pre-coastal tablelands vegetation, aquatic and paludose vegetation of lagoons and marshes, and dicotyl-palmaceous forest. 


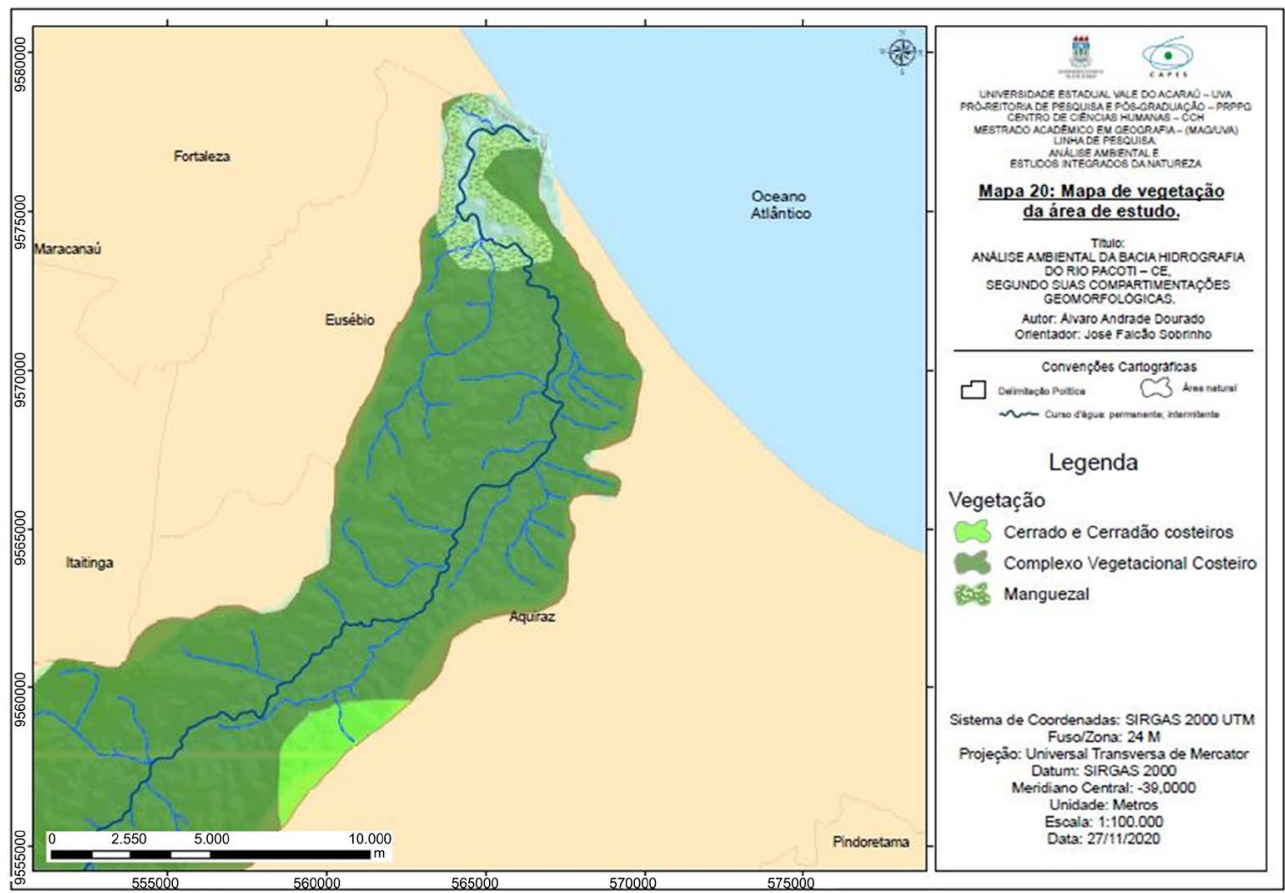

Figure 9. Coastal zone vegetation map. Source: made by the authors (2020).

\subsection{Use and Occupation of the Land}

The predominant economic activities in the coastal region of Ceará are extensive livestock farming (goats, sheep, and cattle), cotton, and subsistence agriculture (corn and beans) on the best soils. However, indiscriminate deforestation and overgrazing have led to the loss of biodiversity of the caatinga and the expansion of agricultural activities, and without the use of techniques to protect the soil and water resources, they are making extensive areas of the outback depression vulnerable to desertification [11].

In the coastal zone, agricultural activities occur because it is the prevailing subsistence activity of local families. Annual, temporary and permanent crops occupy a great area in the coastal zone of the Pacoti River Watershed, Figure 10. Although agriculture prevails, there are areas with the presence of remnant natural vegetation near the Pacoti Riverbed.

\subsection{Conservational Units}

According to data from the Superintendência Estadual do Meio Ambiente do Ceará (State Superintendence of the Environment of Ceará, [16], the Pacoti River has an Area de Proteção Ambiental (Environmental Protection Area, APA). It is a sustainable conservation unit created by Decree No 25.778 on February $15^{\text {th }}$, 2000, and approximately 2914.93 hectares of the municipalities of Fortaleza, Eusébio, and Aquiraz. The access to this conservation unit is the Washington Soares avenue and then the CE-025 road.

In the area shown in Figure 11, there are mangroves, mobile and fixed dunes, and tableland forests. Mangroves are in the fluvial-marine plain representing the 


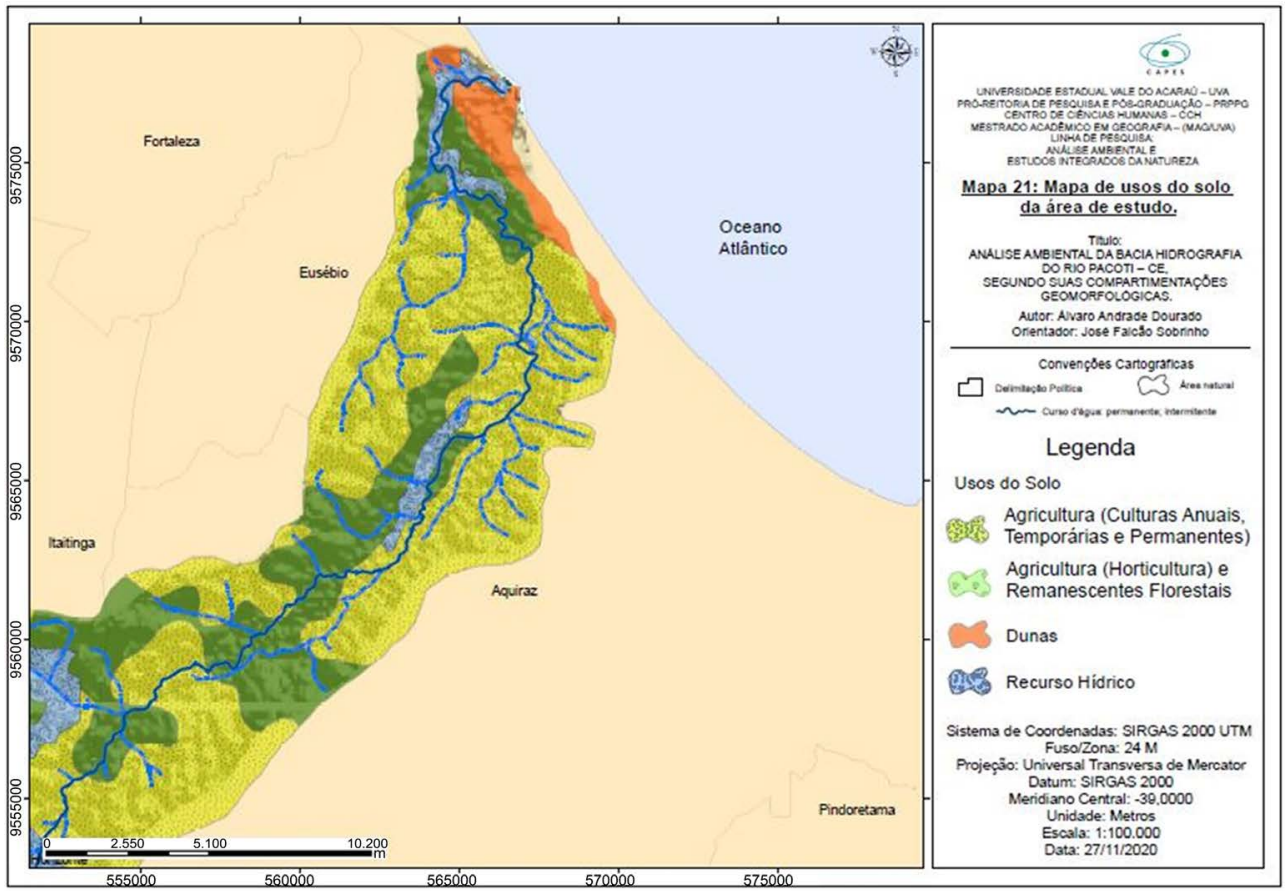

Figure 10. Use and occupation of land in the coastal zone. Source: made by the authors (2020).

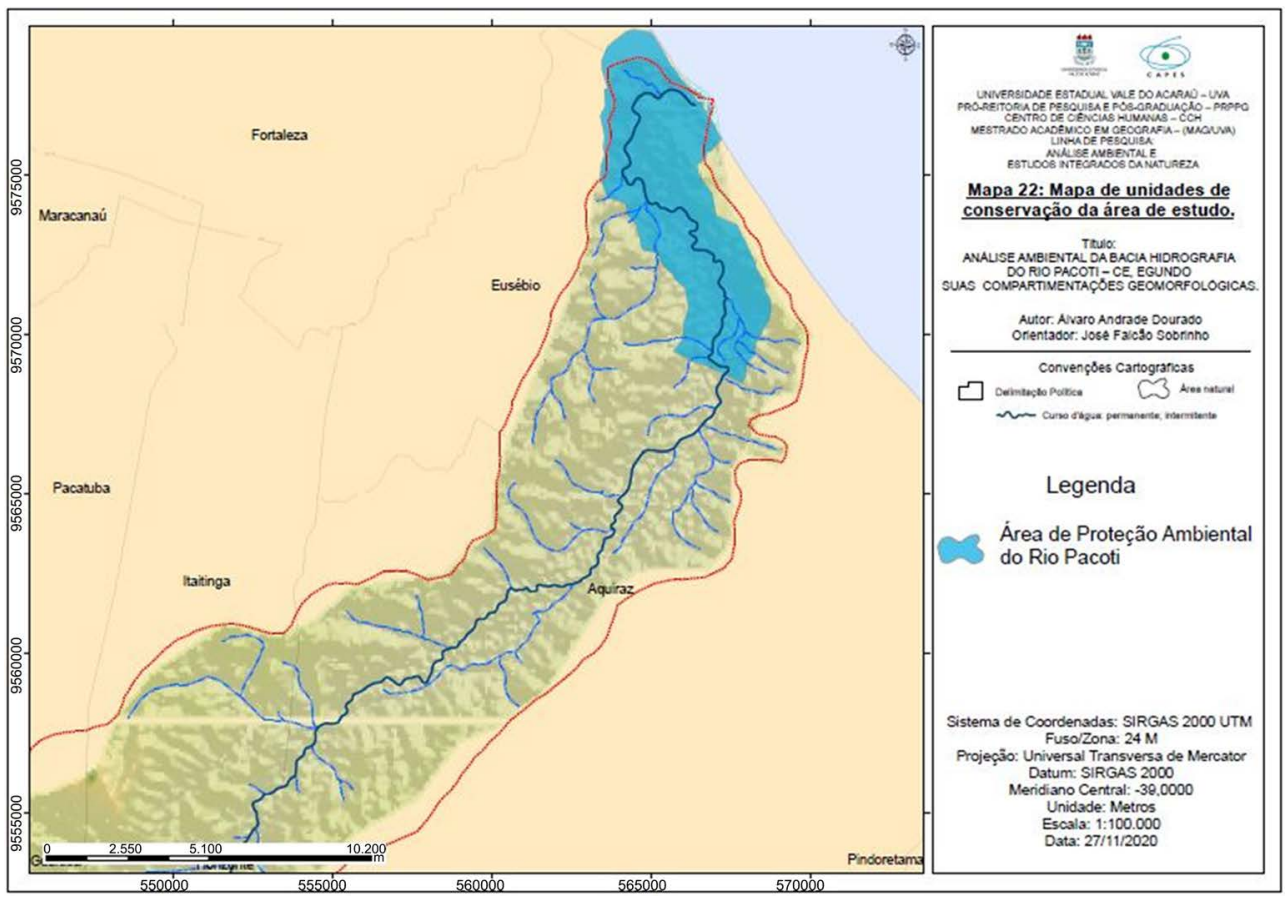

Figure 11. Conservation unit map in the coastal zone. Source: made by the authors (2020).

estuarine zone from the mouth of the river to the vicinity of Aquiraz. The most notorious vegetation along the margins of the estuary is the mangrove forest, called the maritime perennial paludose forest, which stretches about $15 \mathrm{~km}$ from the mouth of the river and occupies around $150 \mathrm{~km}^{2}$. According to studies carried out in the Pacoti River estuarine zone, it has 158 hectares of mangroves dis- 
tributed along the waterways to where the tides have influence. Contiguous to the mangrove area, there is a transitional zone formed by grasses, characterizing the change in vegetation typology. After this narrow zone, the vegetation is typical of the coastal zone, which involves the coastal tableland and dune vegetation [16].

According to studies [16], the fauna is diversified because of the variety of ecosystems. The mangrove area is composed of invertebrates belonging to the groups of decapod crustaceans. There are reptiles, birds, and mammals in the dunes and tableland, besides aquatic species in the estuarine zone.

The residents of Fortaleza, Eusébio, and Aquiraz, along with tourists, enjoy the environmental richness of the area through tourism and leisure activities.

Within the limits of the APA, nine communities survive directly from the use of natural resources, basically from subsistence agriculture, fishing and tourism-related activities: the beach communities of Abreulândia, Porto das Dunas, Fazendinha, Tupuiú, Jacundá, Piranha, Mangabeira and Vila Cabral [16].

The main problems in the APA are the result of human action caused by real estate speculation with the construction of summer houses, gated communities, and hotel developments, disposal of solid waste on the banks of the spring, occupation by residences in the area of permanent preservation of the river, and vehicle traffic on the dunes.

The main prohibited activities are the implantation or expansion of civil construction without environmental licensing; suppression of vegetation; use of fire without authorization from SEMACE; activities that may pollute or degrade the water resources covered by the APA; dumping of effluents, waste, and debris capable of causing damage to the environment; intervention in areas of permanent preservation such as the water resources, dunes, and mangrove ecosystem.

\section{Conclusions}

The geoprocessing techniques of digital images were indispensable since they assisted the physical characterization of the natural units in the Pacoti River Watershed, specifically in its coastal zone.

In addition, the GIS helped in the characterization of natural landscape units not only in the coastal zone, but also in their particularities of the relief features. It stands out the diversities in the geological structure, pedology, and vegetation under similar climatic conditions.

The local modification and damage caused by using the land are noticeable. Therefore, there must be an environmental protection area subject to the organic laws of the Brazilian legislation.

However, the use of geoprocessing techniques demonstrates a viable and appropriate alternative for the characterization and monitoring of areas of interest for preservation, which contribute to decisions about the conservation of natural conditions.

The suggestion here is that the environmental agencies use more geoprocess- 
ing techniques to monitor areas of interest, such as the coastal zone, to support decision-making. The reason is that they have proven to be a reliable alternative for this purpose.

\section{Conflicts of Interest}

The authors declare no conflicts of interest regarding the publication of this paper.

\section{References}

[1] Pinheiro, L.S., Medeiros, C. and Morais, J.O. (2006) Erosive Processes Monitoring Linked to the Estuarine Evolution Systems Nearby Aguas Belas, Cascavel, Ceará, Brazil. Journal of Coastal Research, 39, 1403-1406.

[2] Falcão Sobrinho, J. (2006) O Relevo, Elemento e Âncora, na dinâmica da paisagem do vale, verde e cinza, do Acaraú, no estado do Ceará. 300 f. Tese (Doutorado)—Curso de Faculdade de Filosofia, Letras e Ciências Humanas, Departamento de Geografia, Universidade de São Paulo, São Paulo.

[3] FUNCEME (2020) Fundação Cearense de Meteorologia e Recursos Hídricos. Postos Pluviométricos.

[4] CPRM (2003) Atlas digital de geologia e recursos minerais do Ceará. Mapas na escala 1:500,000. Serviço Geológico do Brasil, Brasília.

[5] Instituto de Pesquisa e Estratégia Econômica do Ceará (2020) Gerência de estatísticas, Geografia e informações. Instituto de Pesquisa e Estratégia Econômica do Ceará, Fortaleza. https://www.ipece.ce.gov.br/estatistica-e-geografia/

[6] COGERH (2016) COMITÊ DE BACIAS HIDROGRÁFICAS DO CEARÁ (Ceará). Agência Nacional de Águas-Ana. Comitê de Bacias.

[7] De Biasi, M. (1993) A carta clinográfica: Os métodos de representação e sua confecção. Revista Do Departamento De Geografia, 6, 45-60. https://doi.org/10.7154/RDG.1992.0006.0004

[8] Cavalcante, A.P.B., et al. (1997) Desenvolvimento Sustentável e Planejamento: Bases Teóricas e Conceituais. UFC-Imprensa Universitária, Fortaleza.

[9] Lima, E.C. (2004) Análise e manejo geoambiental das nascentes do alto rio Acaraú: Serra das Matas-CE. 178 f. Dissertação (Mestrado)-UECE, Fortaleza.

[10] Instituto Nacional de Pesquisas Espaciais (2020) Centro Regional do Nordeste. Brasília. http://www.inpe.br/crn/

[11] Brandão, R.L. (2014) Geodiversidade do estado do Ceará/Organização Ricardo de Lima Brandão [e] Luís Carlos Bastos Freitas-Fortaleza: CPRM.

[12] Marino, M.T.R.D., Freire, G.S.S. and Horn Filho, N.O. (2012) Aspectos geológicos e geomorfológicos da zona costeira entre as praias do Futuro e Porto das Dunas, região metropolitana de Fortaleza, (RMF), Ceará, Brasil. Revista de Geologia, 25, 77-96. http://www.periodicos.ufc.br/geologia/article/view/1342

[13] da Silva, M.S.L. and de Oliveira Neto, M.B. (2011) Ageitec-Agência Embrapa de Informação Tecnológica.

http://www.agencia.cnptia.embrapa.br/gestor/territorio_mata_sul_pernambucana/a rvore/CONT000gt7eon7k02wx7ha087apz2axe8nfr.html

[14] Castro, A.S.F., Moro, M.F. and de Menezes, M.O.T. (2012) O Complexo Vegetacional da Zona Litorânea no Ceará: Pecém, São Gonçalo do Amarante. Acta Bota- 
nica Brasilica, 26, 108-124. https://doi.org/10.1590/S0102-33062012000100013

http://www.scielo.br/scielo.php?script=sci_arttext\&pid=S0102-33062012000100013 \&lng=en\&nrm $=$ iso

[15] Figueiredo, M.A. (1997) A cobertura vegetal do estado do Ceará (unidades fitoecológicas). In: Governo do Ceará, Ed., Atlas do Ceará, Vol. 1, Edições IPLANCE, Fortaleza, 28-29.

[16] Superintendência Estadual do Meio Ambiente-Semace (2010) Área de Proteção Ambiental do Rio Pacoti.

https://www.semace.ce.gov.br/2010/12/08/area-de-protecao-ambiental-do-rio-pacot i/ 